• 研究报告・

\title{
八大公山国家级自然保护区不同生境 蝶类群落特征与月动态
}

\author{
陈梦悦 1,2 吴雨恒 ${ }^{1,2}$ 廖承清 1,2 马方舟 ${ }^{*}$ 王 星 ${ }^{1,2 *}$ \\ 1 (湖南农业大学植物保护学院, 长沙 410128) \\ 2 (植物病虫害生物学与防控湖南省重点实验室, 长沙 410128) \\ 3 (生态环境部南京环境科学研究所/国家环境保护生物安全重点实验室, 南京 210042)
}

摘要: 为了解八大公山国家级自然保护区内的蝴蝶群落组成及海拔分布, 作者于2016-2018年间对该区域不同生 境的蝴蝶群落进行了系统调查和多样性分析, 并持续观测其群落的月动态变化。本研究共记录蝴蝶6,164只, 隶属 于5科107属191种。低海拔(250-450 m)生境记录到的蝴蝶以风蝶亚科为主, 高海拔(1,200-1,400 m)生境以粉蝶亚科 为主, 而中海拔 $(700-900 \mathrm{~m})$ 生境无明显的蝴蝶优势类群。相似性分析结果表明, 各生境存在很高比例的共有种 (59\%以上), 这些共有种在不同生境的个体数分布存在很大的差异。季节动态分析结果表明, 八大公山蝴蝶群落的 物种数、个体数及多样性指数在4-6月逐渐上升, 7月达到峰值, 8-9月逐渐下降。总体来说, 八大公山的蝴蝶群落组 成沿海拔梯度呈现垂直分布差异, 高海拔与低海拔存在明显的异质性, 中海拔则呈现出一种过渡状态; 且八大公 山不同海拔的蝴蝶群落表现出较为一致的季节动态, 都具有很高比例的物种更替; 相对于低海拔, 高海拔生境蝴 蝶群落的活跃期更短, 物种的时间周转率更高。

关键词: 物种多样性; 月动态; 蝴蝶; 八大公山; 生境; 海拔

\section{The community characteristics and month dynamics of butterfly at different habitats in the Badagongshan National Nature Reserve}

\author{
Mengyue Chen ${ }^{1,2}$, Yuheng $\mathrm{Wu}^{1,2}$, Chengqing Liao ${ }^{1,2}$, Fangzhou $\mathrm{Ma}^{3^{*}}$, Xing Wang ${ }^{1,2^{*}}$ \\ 1 College of Plant Protection, Hunan Agricultural University, Changsha 410128 \\ 2 Hunan Provincial Key Laboratory for Biology and Control of Plant Diseases and Insect Pests, Changsha 410128 \\ 3 Nanjing Institute of Environmental Sciences, Ministry of Ecology and Environment; National Key Laboratory of \\ Biosafety, Ministry of Ecology and Environment, Nanjing 210042
}

\begin{abstract}
To explore the butterfly community composition and its altitude distribution in the Badagongshan National Nature Reserve, we investigated and analyzed the butterfly populations of different habitats at different altitudes, and continuously observed the monthly dynamics of their populations in 2016-2018. In this study, we recorded 6,164 butterfly individuals, belonging to 5 families, 107 genera, and 191 species. The survey results showed that the butterfly individuals recorded in low-altitude (250-450 m) and high-altitude (1,200-1,400 m) habitats were mainly Popilioninae and Pierinae, respectively, but mid-altitude (700-900 m) habitats did not have obvious dominant butterfly groups. Similarity analyses showed that there was a high proportion of common species (> 59\%) in each habitat, but the individual distribution of these species in different habitats was different. Seasonal dynamic analyses showed that the butterflies in the Badagongshan were in the rising period from April to June including the species, individuals and diversity indices, usually reaching a peak in July, and then gradually decreasing from August to September. In general, the composition of the butterfly community in the Badagongshan is vertically distributed along the altitude gradient with heterogeneity between high and low altitude habitats and a transitional state at the middle altitude. The butterfly community in the Badagongshan showed consistent seasonal dynamics with a high percentage of
\end{abstract}


species turnover. High altitude habitats had a shorter active period and higher species turnover than lower altitudes.

Key words: species diversity; month dynamics; butterfly; Badagongshan; habitat; altitude

1986年, 经国务院批准, 湖南省张家界八大公 山入选为我国首批国家级自然保护区。它是目前亚 热带地区保存最完整、面积最大的原始次生林区, 属 于森林生态系统类型自然保护区, 具有复杂多样的 生态环境和丰富的动植物资源, 被国内外誉为“绿色 宝库” “世界罕见的物种基因库” “天然博物馆”。

蝴蝶隶属于节肢动物门昆虫纲鳞翅目, 对环境 变化较为敏感, 许多种类已被作为生态系统健康状 况与气候变化的指示生物 (Mullany et al, 2018; Sambhu et al, 2018; 马方舟等, 2018)。通过对区域内 蝴蝶种群的结构和分布情况进行监测, 能在一定程 度上衡量区域生境质量及生物多样性的变化情况 (Laesen, 1988; Kunte, 1997; Kocher, 2000; Xu et al, 2017)。

为了有效地保护并利用八大公山国家级自然 保护区(以下简称八大公山)的环境和资源, 在我国 生态环境部蝴蝶监测计划——全国蝴蝶多样性观 测网络(China BON-Butterflies)项目支持下(马方舟 等, 2018), 我团队于2016-2018年对该区域内的蝴 蝶群落进行了较为系统的调查, 并就不同生境的蝴 蝶群落特征及月间动态进行分析, 以期为该保护区 蝴蝶群落物种多样性的保护及可持续利用提供理 论基础。

\section{研究方法}

\section{1 观测地点与样线设置}

八大公山位于湖南省张家界市桑植县境内, 地 处武陵山脉的北端, 澧水水系和清江水系分水岭南 翼。地理坐标为 $29^{\circ} 39^{\prime} 18^{\prime \prime}-29^{\circ} 49^{\prime} 48^{\prime \prime} \mathrm{N}$, $109^{\circ} 41^{\prime} 45^{\prime \prime}-110^{\circ} 09^{\prime} 50^{\prime \prime} \mathrm{E}$, 海拔346-1,890 m, 总面 积20,000 ha (卢志军, 2011)。本区属于北亚热带山地 湿润季风气候且山地森林小气候十分显著, 冬春长, 夏秋短, 夏季随海拔升高而缩短, 冬季随海拔升高 而延长。年均降水量为2,105.4 mm, 主要集中在5-6 月, 全年相对湿度在 $90 \%$, 属于十分湿润地区。全区 森林覆盖率达 $94.1 \%$, 活立木蓄积量为 110.4 万 $\mathrm{m}^{3}$ (卢志军, 2011; 吴雨恒等, 2016)。
综合考虑蝴蝶适宜的栖境类型、寄主分布范 围、生态习性及八大公山的林相分布、海拔高度和 功能区类型等因素, 本次调查在保护区内共布设5 条2 $\mathrm{km}$ 长的样线(图1), 每条样线均分为 10 个样段, 每段 $200 \mathrm{~m}$ (马方舟等, 2018)。样线 1 (生境A)和样线 2 (生境B)位于低海拔(250-450 m) 的河谷, 植被类 型分别为河谷灌丛和常绿阔叶林; 样线3 (生境C)位 于中海拔的半山陡坡(海拔700-900 m), 植被类型 为落叶与常绿阔叶混交林; 样线 4 (生境 $\mathrm{D}$, 海拔 1,200-1,300 m)及样线5 (生境E, 海拔1,300-1,400 m) 位于高海拔的山脊, 植被类型分别为落叶阔叶林和 针阔叶混交林。

\section{2 观测方法和时间}

采用Pollard (1977)样线计数法: 每次调查由3 人进行, 其中 2 人负责网捕, 1 人负责记录。调查时的 行走速度根据栖息地类型和蝴蝶数量而定, 通常为 $2 \mathrm{~km} / \mathrm{h}$ 。记录样线左右 $2.5 \mathrm{~m}$ 、上方 $5 \mathrm{~m}$ 、前方 $5 \mathrm{~m}$ 范 围内见到的所有蝴蝶的种类和数量(不记录身后的 蝴蝶, 避免重复计数)。若数量过多则采用拍照的形 式进行计数, 对于不能确定的种类, 网捕后进行鉴 定, 种类确定后原地释放; 而网捕后当场不能确定 的种类则编号带回实验室鉴定。2016-2018年，于每 年的 4-9月每月调查 1 次, 原则上两次调查间隔 25-30天左右; 若遇阴雨天气则向后顺延 1 天(马方

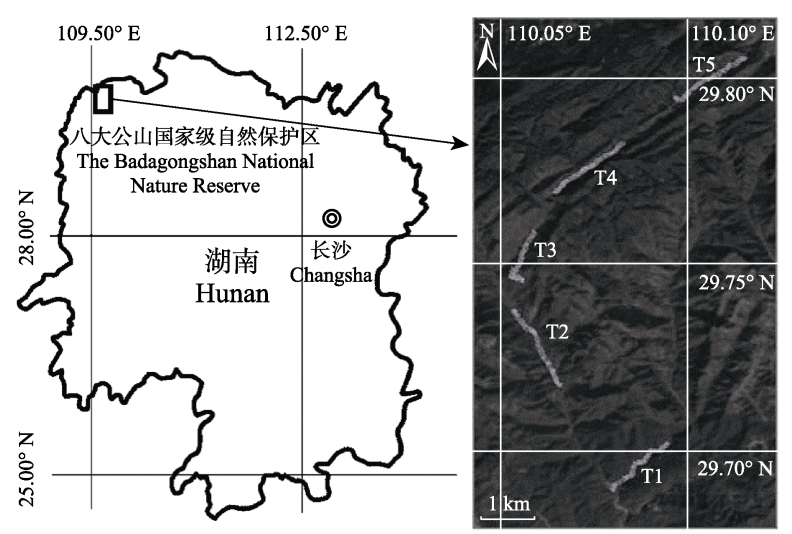

图1八大公山国家级自然保护区位置及蝴蝶调查样线示意图 Fig. 1 Location of the Badagongshan National Nature reserve and transects of butterfly 
舟等, 2018)。观测在气温高于 $18^{\circ} \mathrm{C}$ 、云量少于 $40 \%$ 、 风速小于四级 $(<20 \mathrm{~km} / \mathrm{h})$ 时进行; 观测时间一般在 9:00-16:00之间; 夏季观测时避开极热时段。种类鉴 定参考《中国蝴蝶分类与鉴定》(周尧, 1998)、《中 国昆虫生态大图鉴》(张巍巍和李元胜, 2011)、《中 国蝴蝶图鉴》(武春生和徐堉峰, 2017)。

\section{3 数据处理}

通过Google Earth定位系统对观测轨迹进行位 点校对, KML格式导出。运用Excel 2016及SPSS 22 对调查数据进行统计分析。

\subsection{1 $\alpha$ 多样性分析}

采用Margalef丰富度指数 $(R)$ (Margalef, 1958)、 Shannon-Wiener多样性指数 $\left(H^{\prime}\right)$ (马克平和刘玉明, 1994)、Simpson优势集中性指数 $(D)$ (马克平和刘玉 明, 1994)和Pielou均匀度指数 $(J)$ (马克平和刘玉明, 1994)对八大公山蝶类群落 $\alpha$ 多样性进行评估, 各指

$$
\begin{aligned}
& R=(S-1) / \ln N \\
& H^{\prime}=-\sum P_{\mathrm{i}} \ln P_{\mathrm{i}} \\
& D=1-\sum P_{i}^{2} \\
& J=H^{\prime} / \ln S
\end{aligned}
$$

以上公式中, $S$ 为物种数, $N$ 为个体数, $P_{\mathrm{i}}$ 为物种 $\mathrm{i}$ 的个 体数占群落内总个体数的比例。

我们对蝴蝶群落个体数进行分析前, 先对其进 行 $\log (x+1)$ 对数转换, 以保证其满足正态分布。采 用Kruskal-Wallis 非参数方差分析比较不同生境蝴 蝶群落特征和 $\alpha$ 多样性的差异。

\subsection{2 $\beta$ 多样性分析}

采用Morisita-Horn 个体相似性指数 $\left(C_{\lambda}\right)$ (Morisita, 1959; Horn, 1966)、Sørensen物种相似性指数 $\left(C_{s}\right)$ (Sørensen, 1948; 张镱锂, 1998)对八大公山蝶类群落 $\beta$ 多样性进行评估, 各指数计算公式如下:

$$
\begin{aligned}
& C_{\lambda_{\mathrm{ij}}}=\lambda_{\mathrm{ik}} \sum X_{\mathrm{j}} X_{\mathrm{k}} /\left(\lambda_{\mathrm{j}}+{ }_{\mathrm{k}} \lambda\right) N N \\
& C_{\mathrm{s}}=2 j /(a+b)
\end{aligned}
$$

以上公式中, $\lambda_{\mathrm{j}}=\sum\left(X_{\mathrm{ij}}\left(X_{\mathrm{ij}}-1\right)\right) / N_{\mathrm{j}}\left(N_{\mathrm{j}}-1\right), N_{\mathrm{j}}$ 为 $\mathrm{j}$ 群落总个体数, $N_{\mathrm{k}}$ 为 $\mathrm{k}$ 群落总个体数, $C_{\mathrm{s}}$ 为 $\mathrm{S} ø r e n s e n$ 指数, $j$ 为两个群落共有种数, $a$ 为群落 $\mathrm{A}$ 的物种数, $b$ 为群落 $\mathrm{B}$ 的物种数。

\subsection{3 时间周转率分析}

通过统计各月记录的蝴蝶物种个体数来分析
不同月份蝴蝶群落的结构变化。采用累积物种的速 率 $(\alpha \%)$ 来估算时间周转率(temporal turnover), 即每 次调查到物种的平均值 (mean $\alpha)$ 与生境实际物种数 (cumulative $\alpha$ )的比例(mean $\alpha /$ cumulative $\alpha$ ), 比例 越高说明物种积累的速率越快, 时间周转率越低 (Zamora et al, 2007)。

\section{结果}

\section{1 不同生境蝴蝶群落的物种组成}

本研究共记录蝴蝶6,164只, 隶属于107属191 种(附录1)。各蝴蝶亚科在八大公山不同生境的分布 情况见表 1 , 位于高海拔的生境 $\mathrm{D}$ 和生境 $\mathrm{E}$ 的蝴蝶群 落主要由粉蝶亚科物种构成, 个体数分别占生境总 个体数的 $48.38 \%$ 和 $51.14 \%$; 其次是眼蝶亚科(生境 D: $8.33 \%$; 生境 E: $10.46 \%$ ) 和灰蝶亚科 (生境 D: 7.74\%; 生境E: 8.19\%)。低海拔区域的生境A、生境 $\mathrm{B}$ 的蝴蝶群落中占比最高的为风蝶亚科, 分别占生 境总个体数的 $25.89 \%$ 和 $36.61 \%$; 其后依次是黄粉 蝶亚科(生境A: $16.72 \%$; 生境B: 10.92\%)和线蛱蝶 亚科(生境A: 13.90\%; 生境B: 9.78\%)。生境 C的蝴蝶 群落较为均匀, 没有明显的优势类群。凤蝶亚科和 粉蝶亚科分别占生境总个体数的 $17.79 \%$ 和 $15.10 \%$; 其次是线蛱蝶亚科、眼蝶亚科和灰蝶亚科, 分别占 生境总个体数的 $11.24 \% 、 10.57 \%$ 和 $10.07 \%$ 。

不同生境蝴蝶物种-多度等级见图2。生境 $\mathrm{D}$ 和 生境 $\mathrm{E}$ 的优势性更强, 个体数排名前三的物种分别 是黑纹粉蝶 (Pieris melete) (生境D: 24.58\%; 生境E: 28.04\%)、飞龙粉蝶 (Talbotia naganum) (生境 D: 15.18\%; 生境 E: 15.40\%) 和酒青斑粉蝶 (Delias sanaca) (生境D: 6.46\%; 生境E: 6.32\%)。而位于中、 低海拔的3种生境则优势性相对较弱，生境 $\mathrm{A}$ 个体 数排名前三的为宽边黄粉蝶 (Eurema hecabe, 14.72\%)、宽带美凤蝶(Papilio nephelus, 7.55\%)和二 尾蛱蝶(Polyura narcaea, 6.39\%); 生境B个体数排名 前三的为: 碧翠凤蝶(Papilio bianor, 11.13\%)、巴黎 翠凤蝶(P. paris, 6.95\%)和东方菜粉蝶(Pieris canidia, $5.87 \%)$; 生境 C个体数排名前三的为: 斑星弄蝶 (Celaenorrhinus maculosus, 7.55\%)、黑纹粉蝶(6.54\%) 和碧翠凤蝶(6.38\%)。

\section{2 不同生境蝴蝶群落多样性}

2016-2018年，不同生境的蝴蝶群落多样性指 
表1 各蝴蝶类群在八大公山国家级自然保护区不同生境的分布情况

Table 1 The distribution of butterfly groups in different habitats in the Badagongshan National Nature reserve

\begin{tabular}{|c|c|c|c|c|c|c|c|}
\hline \multirow{2}{*}{\multicolumn{2}{|c|}{$\begin{array}{l}\text { 科 } \\
\text { Family }\end{array}$}} & \multirow{2}{*}{$\begin{array}{l}\text { 亚科 } \\
\text { Subfamily }\end{array}$} & \multicolumn{5}{|c|}{ 占生境内个体数的相对比例 Relative ratio of the number of individuals in habitats (\%) } \\
\hline & & & $\begin{array}{l}\text { 生境A } \\
\text { Habitat A }\end{array}$ & $\begin{array}{l}\text { 生境B } \\
\text { Habitat B }\end{array}$ & $\begin{array}{l}\text { 生境C } \\
\text { Habitat C }\end{array}$ & $\begin{array}{l}\text { 生境D } \\
\text { Habitat D }\end{array}$ & $\begin{array}{l}\text { 生境E } \\
\text { Habitat E }\end{array}$ \\
\hline 凤蝶科 & Papilionidae & 凤蝶亚科 Popilioninae & 25.89 & 36.61 & 17.79 & 9.70 & 4.15 \\
\hline \multirow[t]{3}{*}{ 粉蝶科 } & Pieridae & 粉蝶亚科 Pierinae & 2.97 & 8.50 & 15.10 & 48.38 & 51.14 \\
\hline & & 黄粉蝶亚科 Coliodinae & 16.72 & 10.92 & 7.89 & 2.74 & 2.27 \\
\hline & & 合计 Total & 19.69 & 19.42 & 22.99 & 51.12 & 53.41 \\
\hline \multirow[t]{5}{*}{ 灰蝶科 } & Lycaenidae & 灰蝶亚科 Lycueninae & 4.49 & 8.70 & 10.07 & 7.74 & 8.19 \\
\hline & & 蚬蝶亚科 Riodininae & 6.68 & 2.43 & 0.67 & 1.47 & 3.16 \\
\hline & & 银灰蝶亚科 Curetinae & 1.85 & 1.55 & 1.01 & 0.20 & 0.00 \\
\hline & & 云灰蝶亚科 Miletinae & 0.29 & 0.13 & 0.50 & 0.00 & 0.10 \\
\hline & & 合计 Total & 13.31 & 12.81 & 12.25 & 9.41 & 11.45 \\
\hline \multirow[t]{9}{*}{ 蛱蝶科 } & Nymphalidae & 线蛱蝶亚科 Limenitinae & 13.90 & 9.78 & 11.24 & 5.09 & 4.34 \\
\hline & & 眼蝶亚科 Satyrinae & 1.41 & 3.64 & 10.57 & 8.33 & 10.46 \\
\hline & & 蛱蝶亚科 Nymphalinae & 5.22 & 2.43 & 1.51 & 3.62 & 1.48 \\
\hline & & 鳌蛱蝶亚科 Choraxinae & 6.39 & 2.56 & 0.34 & 0.29 & 0.00 \\
\hline & & 丝蛱蝶亚科 Cyrestinae & 2.97 & 3.51 & 7.55 & 0.59 & 0.20 \\
\hline & & 闪蛱蝶亚科 Apiturinae & 2.10 & 2.56 & 2.68 & 1.08 & 0.59 \\
\hline & & 㗒蝶亚科 Libytheinae & 0.49 & 0.61 & 2.85 & 1.67 & 1.97 \\
\hline & & 袖蝶亚科 Heliconiinae & 0.34 & 0.74 & 0.34 & 2.15 & 2.07 \\
\hline & & 合计 Total & 32.82 & 25.83 & 37.08 & 22.82 & 21.11 \\
\hline \multirow{5}{*}{\multicolumn{2}{|c|}{ 弄蝶科 Hesperiidae }} & 花弄蝶亚科 Pyrginae & 2.88 & 3.57 & 8.72 & 4.02 & 5.63 \\
\hline & & 弄蝶亚科 Hesperiinae & 5.02 & 1.69 & 0.67 & 2.45 & 2.27 \\
\hline & & 坚翅弄蝶亚科 Coeliadinae & 0.20 & 0.00 & 0.50 & 0.10 & 0.79 \\
\hline & & 链弄蝶亚科 Hcrcroptcrinae & 0.00 & 0.00 & 0.00 & 0.00 & 0.79 \\
\hline & & 合计 Total & 8.10 & 5.26 & 9.89 & 6.57 & 9.48 \\
\hline
\end{tabular}

数间存在显著差异(Kruskal-Wallis: 物种数: $H=$ 33.529, $P<0.05$; 个体数: $H=33.404, P<0.05$; 丰 富度指数: $H=34.997, P<0.05$; Shannon-Wiener多 样性指数: $H=39.531, P<0.05$; 优势度指数: $H=$ 15.668, $P<0.05$; 均匀度指数: $H=30.296, P<$ 0.05 )(图3)。就物种数及个体数而言, 低海拔的生境 $\mathrm{A}$ 的蝴蝶物种数和个体数最多, 其后依次为低海拔 的生境 $\mathrm{B} 、$ 高海拔的生境 $\mathrm{D}$ 和生境 $\mathrm{E}$, 中海拔的生境 $\mathrm{C}$ 物种相对最少(图3)。低海拔区的生境 $\mathrm{A}$ 和生境 $\mathrm{B}$ 的 Shannon-Wiener多样性指数显著高于高海拔区的生 境 $\mathrm{D}$ 和生境 $\mathrm{E}$, 而中海拔的生境 $\mathrm{C}$ 与其他 4 个生境间 无显著差异。低海拔区的生境 $\mathrm{A}$ 和中海拔区的生境 $\mathrm{C}$ 的丰富度指数显著高于高海拔区的生境 $\mathrm{E}$, 其余生 境间无显著性差异。位于中海拔的生境 $\mathrm{C}$ 的蝴蝶群 落最为均匀, 均匀度指数显著高于低海拔区的生境 $\mathrm{A}$ 和高海拔区的生境 $\mathrm{D}$ 和生境 $\mathrm{E}$, 与低海拔区的生境
$\mathrm{B}$ 间无显著差异。高海拔区的生境 $\mathrm{D}$ 和生境 $\mathrm{E}$ 表现出 了更强的优势集中性，显著高于低海拔区的生境 $\mathrm{A} 、$ 生境 $\mathrm{B}$ 和中海拔区的生境 $\mathrm{C}$ 。这表明前两者的蝴 蝶群落结构更为单一, 优势度更为集中。

\section{3 不同生境蝴蝶群落的相似性}

不同生境的蝴蝶群落Sørensen相似性分析结果 表明，不同生境间共有种的比例非常高，达59.00\% 以上(表2对角线上方)。Morisita-Horn相似性分析发 现位于相近海拔区域的生境间(生境 $\mathrm{A}$ 和生境 $\mathrm{B}$ 、生 境 $\mathrm{B}$ 和生境 $\mathrm{C}$ 以及生境 $\mathrm{D}$ 和生境 $\mathrm{E}$ )均保持了很高的 相似性(70.77\%、78.16\%及97.33\%)（表2对角线下 方)。但不同海拔区域的生境之间相似性极低, 尤其 是高低海拔区的生境之间, 最低的相似度出现在生 境 $\mathrm{A}$ 和生境 $\mathrm{E} 之$ 间，仅6.80\%; 其次是生境 $\mathrm{B}$ 和生境 $\mathrm{E}$ 之间，为 $9.59 \%$ 。这表明虽然不同生境间的物种具有 很大程度的重叠, 但是这些共有种在不同生境中的 


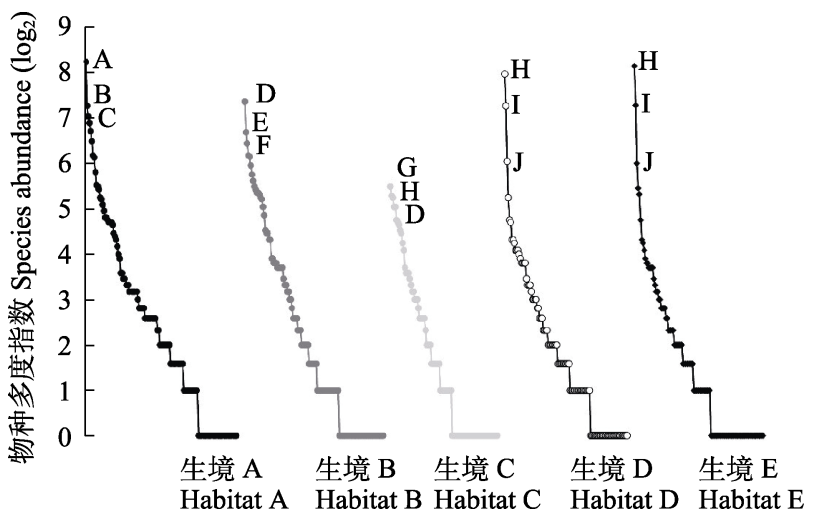

图2八大公山国家级自然保护区不同生境蝴蝶物种的多度 等级。多度通过 $\log _{2}$ 进行转换, 各物种按在生境中的多度顺 序进行排布, 仅标注了各生境多度排名前三的物种。A: 宽 边黄粉蝶; B: 宽带美凤蝶; C: 二尾蛱蝶; D: 碧翠凤蝶; $\mathrm{E}$ : 巴黎翠凤蝶; $\mathrm{F}$ : 东方菜粉蝶; G: 斑星弄蝶; H: 黑纹粉 蝶; I: 飞龙粉蝶; J: 酒青斑粉蝶。

Fig. 2 Rank-abundance plots of butterfly communities in different habitats in the Badagongshan National Nature reserve. Abundances were $\log _{2}$ transformed and species were ordered from the most abundant species to the least. Only the three most abundant species in each habitat are indicated. A, Eurema hecabe; B, Papilio nephelus; C, Polyura narcaea; D, Papilio bianor; E, Papilio paris; F, Pieris canidia; G, Celaenorrhinus maculosus; H, Pieris melete; I, Talbotia naganum; J, Delias sanaca.

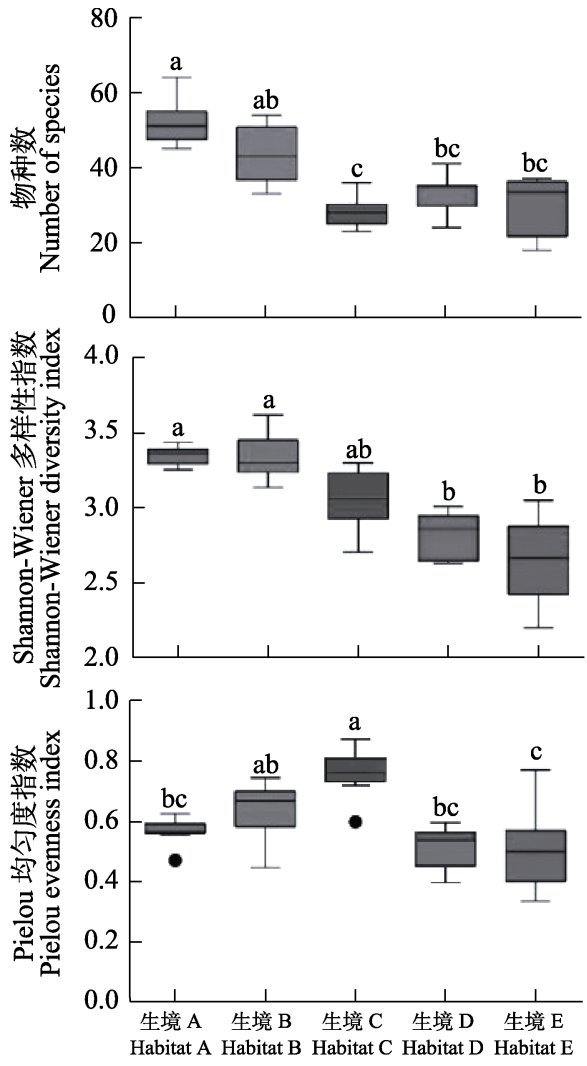

发生比例存在很大差异。位于中海拔的生境 $\mathrm{C}$ 的 Morisita-Horn个体相似性指数介于高低海拔之间, 说明中海拔区的蝴蝶群落组可能为过渡类型。

\section{4 不同生境蝴蝶群落的月动态}

各生境蝴蝶群落物种数及个体数的月动态见 图4。就物种数而言, 各月的变化趋势相近, 但仍存 在一定的差异：除7月外，在大多数观测时间，低海 拔的生境A和生境B的物种数明显高于其他生境。4 月温度较低, 各生境蝴蝶的物种数和个体数都很少; 5-6月为上升期。随着温度的升高, 各生境的蝴蝶物 种数和个体数都开始增加, 低海拔的生境 $\mathrm{A}$ 和生境 $\mathrm{B}$ 的上升幅度更大; 7 月温度最高, 各生境的物种数 也在此时达到峰值; 8-9月气温开始回落, 低海拔的 生境 $\mathrm{A}$ 和生境 $\mathrm{B}$ 部分种类的蝴蝶活动逐渐下降; 在9 月, 中、高海拔的生境通常只观测到了很少的蝴蝶 活动，而在低海拔的生境 $\mathrm{A}$ 和生境 $\mathrm{B}$ 保有一定的蝴 蝶种类。就个体数而言, 高海拔与低海拔间逐月变 化的趋势也基本相近。

通过统计各生境的物种累积速率(表3)，对各生 境的时间周转率进行分析。各生境的累积物种的
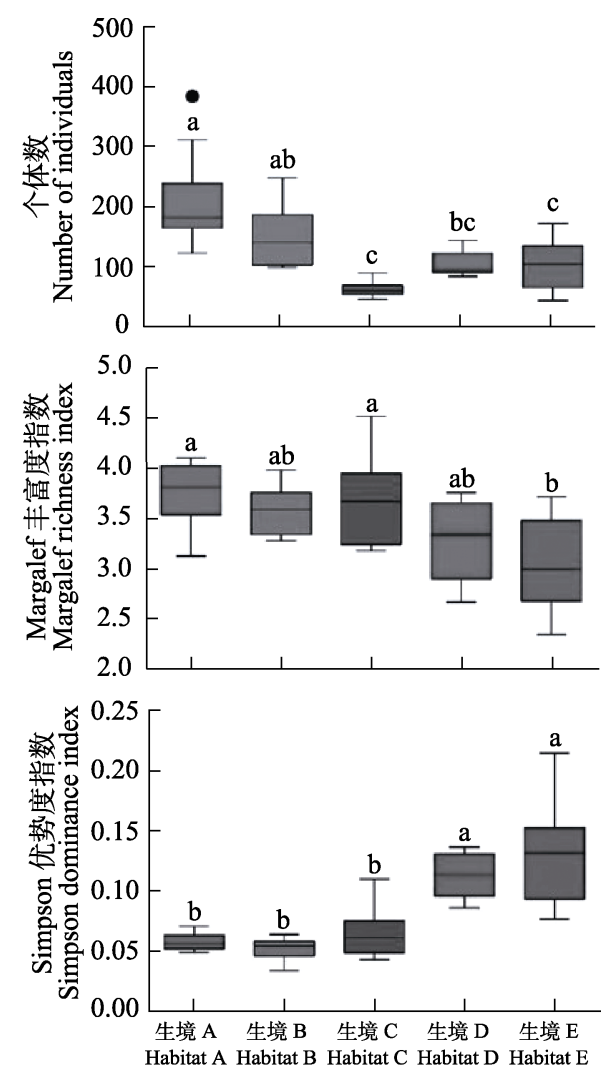

图3八大公山国家级自然保护区不同生境蝴蝶群落多样性指数。同一个图中不同字母代表在 0.05 水平差异显著 $(\boldsymbol{P}<0.05)$ 。 Fig. 3 Diversity indices of butterfly community in different habitats of the Badagongshan National Nature reserve. Different letters in the same figure represent a significant difference at the 0.05 level $(P<0.05)$. 
表2 八大公山国家级自然保护区不同生境间蝴蝶群落的 Sørensen (对角线上方) 和Morisita-Horn相似性指数(对角线 下方)

Table 2 Sørensen (above diagonal) and Morisita-Horn similarity index (below diagonal) of butterflies in different habitats of the Badagongshan National Nature reserve

\begin{tabular}{llllll}
\hline & $\begin{array}{l}\text { 生境A } \\
\text { Habitat A }\end{array}$ & $\begin{array}{l}\text { 生境B } \\
\text { Habitat B }\end{array}$ & $\begin{array}{l}\text { 生境C } \\
\text { Habitat C }\end{array}$ & $\begin{array}{l}\text { 生境D } \\
\text { Habitat D }\end{array}$ & $\begin{array}{l}\text { 生境E } \\
\text { Habitat E }\end{array}$ \\
\hline $\begin{array}{llllll}\text { 生境A } \\
\text { Habitat A }\end{array}$ & & 0.7801 & 0.6791 & 0.6053 & 0.6266 \\
$\begin{array}{l}\text { 生境B } \\
\text { Habitat B }\end{array}$ & 0.7077 & & 0.6765 & 0.6083 & 0.5946 \\
$\begin{array}{l}\text { 生境C } \\
\text { Habitat C }\end{array}$ & 0.5775 & 0.7816 & & 0.6073 & 0.6224 \\
$\begin{array}{l}\text { 生境D } \\
\text { Habitat D }\end{array}$ & 0.1352 & 0.1929 & 0.3905 & & 0.7177 \\
$\begin{array}{l}\text { 生境E } \\
\text { Habitat E }\end{array}$ & 0.680 & 0.959 & 0.3223 & 0.9733 & \\
\hline
\end{tabular}

速率都很低，范围在26\%-36\%。这意味着各月间存 在很高的时间周转率, 蝴蝶群落具有明显的季节变

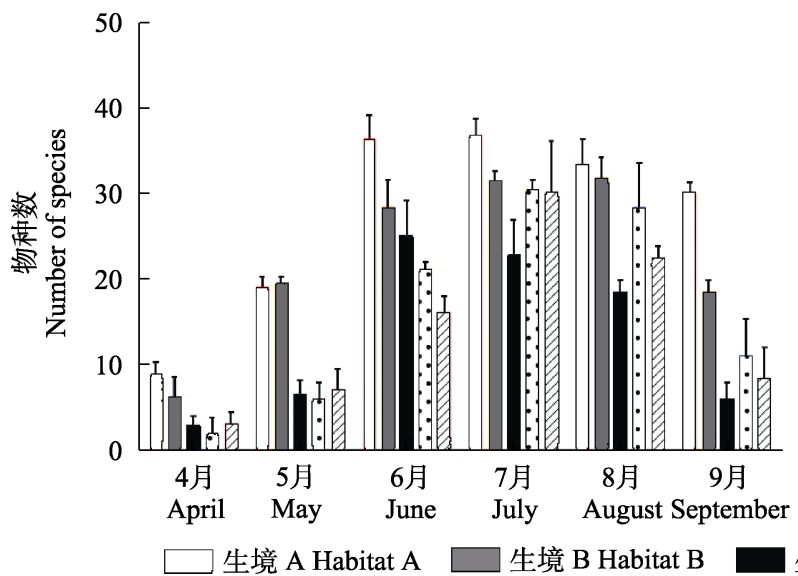

动。与低海拔的生境(生境 $\mathrm{A}$ 和生境 $\mathrm{B}$ )相比, 位于中、 高海拔的生境C、生境 $\mathrm{D}$ 和生境 $\mathrm{E}$ 的时间周转率相对 较高, 物种更替的速率更快。

\section{3 讨论}

本研究的物种组成与湖南其他保护区的蝴蝶 多样性的调查结果基本一致(张佑祥等, 2007; 李密 等, 2011; 向颖等, 2017)。从蝴蝶物种的多度等级可 以看出, 大多数物种仅有很少的个体，优势种的个 体数在总数中占比较高, 符合生态位优先占领假说, 即群落中物种对资源的占有表现为第一优势种优 先占领有限资源的一定部分，第二优势种又占领所 余下资源的一定部分。

蝴蝶群落的分布通常随生境演替具有明显海 拔格局(Lomolino, 2001), 而地形的起伏也能提供类 似屏障的作用(Brown, 2001)。在本研究中, 八大公

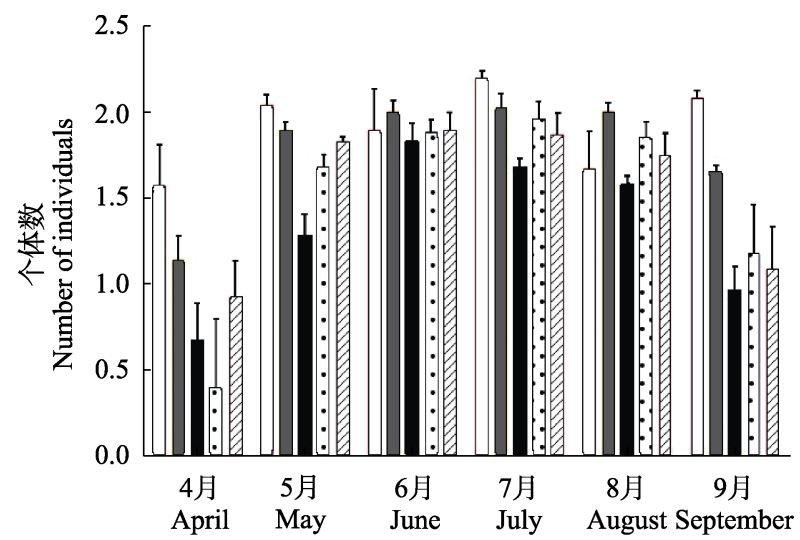

图4 八大公山国家级自然保护区不同生境蝴蝶物种数和个体数的月动态

Fig. 4 Monthly dynamics of the number of species and individuals at different habitats in the Badagongshan National Nature reserve

表3 八大公山国家级自然保护区不同生境蝴蝶群落的逐月物种累积

Table 3 Month by month species accumulation of butterfly community in different habitats of the Badagongshan National Nature reserve

\begin{tabular}{lllll}
\hline 生境类型 & $\begin{array}{l}\text { 累加物种数 } \\
\text { Species cumulative number }\end{array}$ & $\begin{array}{l}\text { 平均物种数 } \\
\text { Average number of species }\end{array}$ & $\begin{array}{l}\text { 累积物种数 } \\
\text { Species accumulation }\end{array}$ & $\begin{array}{l}\text { 物种累积速率 } \\
\text { Species accumulation rate (\%) }\end{array}$ \\
\hline 生境A Habitat A & $166.0 \pm 6.7^{\mathrm{a}}$ & $27.7 \pm 1.1^{\mathrm{a}}$ & $78.7 \pm 4.4^{\mathrm{a}}$ & $35.37 \pm 1.29^{\mathrm{a}}$ \\
生境B Habitat B & $137.0 \pm 10.2^{\mathrm{b}}$ & $22.8 \pm 1.7^{\mathrm{b}}$ & $69.3 \pm 5.2^{\mathrm{ab}}$ & $32.94 \pm 0.06^{\mathrm{a}}$ \\
生境C Habitat C & $82.7 \pm 4.4^{\mathrm{c}}$ & $13.8 \pm 0.7^{\mathrm{c}}$ & $49.7 \pm 2.2^{\mathrm{c}}$ & $27.75 \pm 1.09^{\mathrm{b}}$ \\
生境D Habitat D & $100.0 \pm 7.6^{\mathrm{c}}$ & $16.7 \pm 1.3^{\mathrm{c}}$ & $62.7 \pm 4.1^{\mathrm{bc}}$ & $26.56 \pm 0.53^{\mathrm{b}}$ \\
生境E Habitat E & $88.7 \pm 10.3^{\mathrm{c}}$ & $14.7 \pm 1.7^{\mathrm{c}}$ & $56.0 \pm 5.9^{\mathrm{bc}}$ & $26.33 \pm 0.92^{\mathrm{b}}$ \\
总计 Total & $318.0 \pm 22.7$ & $53.0 \pm 3.8$ & $133.0 \pm 10.8$ & $40.00 \pm 1.54$ \\
\hline
\end{tabular}

表中同一列不同英文字母表示其差异达到显著水平 $(P<0.05)$

Means within the same column followed by the different letters are significantly different $(P<0.05)$ 
山属于典型的中山地貌, 山势陡峭, 高海拔与低海 拔存在明显的异质性。低海拔生境的蝴蝶群落主要 以凤蝶为主, 高海拔以粉蝶为主; 而中海拔则体现 出了群落垂直分布中的中间性和异质性, 其群落结 构比较均匀, 和高低海拔群落均具有一定的相似性, 呈现出一种过渡状态。

蝴蝶群落发生的季节模式取决于多种环境因 素, 如气候条件、寄主资源及蜜源植物的可用性等 (Franzén et al, 2017), 是各项环境因子综合作用的 结果(Pecl et al, 2017)。蝴蝶对栖息地具有专一性, 甚至在每个生命阶段都有不同的栖息地要求, 特别 是幼虫期的取食和成虫期的访花行为与寄主植物 相互作用(Borges et al, 2003; Hardy et al, 2007)。大多 数蝴蝶都需要专门的栖息地, 这些栖息地很容易受 到外部环境的物理因素和生物因素的影响(Leps \& Spitzer, 1990; Spitzer et al, 1993), 如温度、湿度、光 照水平、降雨模式、当地小气候条件、草地类型和 寄主植物物种丰富性和分布等(Hill et al, 2001; Meyer \& Sisk, 2001; Collinge et al, 2003; Menendez et al, 2007)。

本研究中, 八大公山蝴蝶群落的季节发生动态 呈单峰状，这种季节模式在之前也有类似的报道 (王敏等, 2003; Chen et al, 2014; 旦智措等, 2018), 这些研究表明在中国不同气候带的蝴蝶种群具有 明显的季节性。此外, 不同种蝴蝶成虫的寿命差异 很大(Beck, 2008), 羽化时间必须与一定的生境条 件(温湿条件、寄主植物资源、蜜源条件)相适应 (Spitzer et al, 1993), 这或许可以解释八大公山蝴蝶 群落各月间的物种更替。因此, 有必要进一步了解 八大公山的蝴蝶及其寄主植物种类，明确各蝴蝶的 生物学和生态学特性, 以期能深入探讨蝴蝶群落的 种群更替与寄主等条件之间的相互联系。

\section{参考文献}

Beck J (2008) Phylogenetic and ecological correlates with male adult life span of rainforest butterflies. Evolutionary Ecology, 22, 507-517.

Borges RM, Gowda V, Zacharias M (2003) Butterfly pollination and high-contrast visual signals in a low-density distylous plant. Oecologia, 136, 571-573.

Brown J (2001) Mammals on mountainsides: Elevational patterns of diversity. Global Ecology and Biogeography, 10, 101-109.

Chen S, Mao L, Zhang J, Zhou K, Gao J (2014) Environmental determinants of geographic butterfly richness pattern in eastern China. Biodiversity and Conservation, 23, 1453-1467.

Chou I (1998) Classification and Identification of Chinese Butterflies. Henan Science and Technology Publishing House, Zhengzhou. (in Chinese) [周尧 (1998) 中国蝴蝶分 类与鉴定. 河南科学技术出版社, 郑州.]

Collinge SK, Prudic KL, Oliver JC (2003) Effects of local habitat characteristics and landscape context on grassland butterfly diversity. Conservation Biology, 17, 178-187.

Dan ZC, Bao M, Ma CX, Li LL, Hao HW, Cheng F, Cai XZM, Chen ZN (2018) Community structure and butterfly diversity in different habitat types in the Qinghai Yushu Plateau. Acta Ecologica Sinica, 38, 7557-7564. (in Chinese with English abstract) [旦智措, 鲍敏, 马存新, 李雷雷, 郝 会文，成帆，才项卓玛，陈振宁 (2018) 青海玉树高原不 同生境类型蝶类群落结构与多样性. 生态学报, 38, 7557-7564.]

Franzén M, Schrader J, Sjöberg G (2017) Butterfly diversity and seasonality of Ta Phin mountain area (N. Vietnam, Lao Cai province). Journal of Insect Conservation, 21, 465-475.

Hardy PB, Sparks TH, Isaac NJB, Dennis RLH (2007) Specialism for larval and adult consumer resources among British butterflies: Implications for conservation. Biological Conservation, 138, 440-452.

Hill JK, Hamer KC, Tangah J, Dawood M (2001) Ecology of tropical butterflies in rainforest gaps. Oecologia, 128, 294-302.

Horn HS (1966) Measurement of "overlap” in comparative ecological studies. The American Naturalist, 100, 419-424.

Kocher SD, Williams EH (2000) The diversity and abundance of North American butterflies vary with habitat disturbance and geography. Journal of Biogeography, 27, 785-794.

Kunte KJ (1997) Seasonal patterns in butterfly abundance and species diversity in four tropical habitats in northern western Ghats. Journal of Biosciences, 22, 593-603.

Laesen TB (1988) The butterflies of the Nilgiri Mountains of southern India (Lepidoptera: Rhopalocera). Journal of the Bombay Natural History Society, 84, 291-316.

Leps J, Spitzer K (1990) Ecological determinants of butterfly communities (Lepidoptera, Papilionoidea) in the Tam-Dao Mountains, Vietnam. Acta Entomologica Bohemoslovaca, 87, 182-194.

Li M, Zhou HC, Tan JC, Wang P, Liu GH (2011) Butterfly species diversity and its conservation in Wuyunjie National Nature Reserve, Hunan Province of China. Chinese Journal of Applied Ecology, 22, 1585-1591. (in Chinese with English abstract) [李密，周红春，谭济才，王鹏，刘国华 (2011) 乌云界国家级自然保护区蝴蝶物种多样性及其保 护. 应用生态学报, 22, 1585-1591.]

Lomolino MV (2001) Elevation gradients of species-density: Historical and prospective views. Global Ecology \& Biogeography, 10, 3-13.

$\mathrm{Lu} \mathrm{ZJ} \mathrm{(2011)} \mathrm{Brief} \mathrm{introduction} \mathrm{of} \mathrm{Hunan} \mathrm{Badagongshan}$ National Nature Reserve. Biodiversity Science, 19, 271. (in Chinese) [卢志军 (2011) 湖南八大公山国家级自然保护 
区简介. 生物多样性, 19, 271.]

Ma FZ, Xu HG, Chen MM, Tong WJ, Wang CB, Cai L (2018) Progress in construction of China Butterfly Diversity Observation Network (China BON-Butterflies). Journal of Ecology and Rural Environment, 34, 27-36. (in Chinese with English abstract) [马方舟, 徐海根, 陈萌萌, 童文君, 王晨涁, 蔡蕾 (2018) 全国蝴蝶多样性观测网络(China BON-Butterflies) 建设进展. 生态与农村环境学报, 34, 27-36.]

Ma KP, Liu YM (1994) Measurement of biotic community diversity. I. $\alpha$ diversity (Part 2). Chinese Biodiversity, 2, 231-239. (in Chinese) [马克平, 刘玉明 (1994) 生物群落 多样性的测度方法. I. $\alpha$ 多样性的测度方法(下). 生物多样 性, 2, 231-239.]

Margalef DR (1958) Information theory in ecology. General Systematics, 3, 36-71.

Menendez R, Gonzalez-Megıas A, Collingham Y, Fox R, Roy DB, Ohlemuller R, Thomas CD (2007) Direct and indirect effects of climate and habitat factors on butterfly diversity. Ecology, 88, 605-611.

Meyer CL, Sisk TD (2001) Butterfly response to microclimatic conditions following ponderosa pine restoration. Restoration Ecology, 9, 453-461.

Morisita M (1959) Measuring of interspecific association and similarity between communities. Memoirs of the Faculty of Science, Kyushu University, Series E (Biology), 3, 215-235.

Mullany F, Hollands G, Snaddon JL (2018) Immediate impact of a hurricane on the structure of a tropical butterfly community. Biotropica, 50, 487-490.

Pecl GT, Araujo MB, Bell JD, Blanchard J, Bonebrake TC, Chen IC, Clark TD, Colwell RK, Danielsen F, Evengård B, Falconi L, Ferrier S, Frusher S, Garcia RA, Griffis RB, Hobday AJ, Scheepers CJ, Jarzyna MA, Jennings S, Lenoir J, Linnetved FI, Martin VY, McCormack PC, McDonald J, Mitchell NJ, Mustonen T, Pandolfi JF, Pettorelli N, Popova E, Robinson SA, Scheffers BR, Shaw JD, Sorte CJB, Strugnell JM, Sunday JM, Tuanmu MN, Vergés A, Villanueva C, Wernberg T, Wapstra E, Williams SE (2017) Biodiversity redistribution under climate change: Impacts on ecosystems and human well-being. Science, 355, eaai9214.

Pollard E (1977) A method for assessing changes in the abundance of butterflies. Biological Conservation, 12, 115-134.

Sambhu H, Nankishore A, Turton SM, Northfield TD (2018) Trade-offs for butterfly alpha and beta diversity in human-modified landscapes and tropical rainforests. Ecology and Evolution, 8, 12918-12928.

Spitzer K, Novotny V, Tonner M, Leps J (1993) Habitat preferences distribution and seasonality of the butterflies (Lepidoptera, Papilionoidea) in a montane tropical rain forest, Vietnam. Journal of Biogeography, 20, 109-121.

Sørensen TA (1948) Method of establishing groups of equal amplitude in plant sociology based on similarity of species and its application to analyses of the vegetation on Danish commons. Biologiske Skrifter, 5(4), 1-34.

Wang M, Huang GH, Fan XL, Xie GZ, Huang LS (2003) Species diversity of butterflies in Shimentai Nature Reserve, Guangdong. Biodiversity Science, 11, 441-453. (in Chinese with English abstract) [王敏, 黄国华, 范骁凌, 谢国忠, 黄 林生 (2003) 石门台自然保护区蝴蝶物种多样性研究. 生物多样性, 11, 441-453.]

Wu CS, Xu YF (2017) Butterflies of China. The Straits Publishing \& Distribution Group, Fuzhou. (in Chinese) [武 春生, 徐堉峰 (2017) 中国蝴蝶图鉴. 海峡出版发行集 团, 福州.]

Wu YH, Gu ZR, Liao CL, Wang XY, Gu Q, Xiang Y (2016) Research progress of butterflies diversity in the Badagongshan National Nature Reserve. Studies on Central China Insects, 12, 124-128. (in Chinese with English abstract) [吴雨恒, 谷志容, 廖春林, 王秀英, 谷祺, 向阳 (2016) 八大公山国家级自然保护区蝴蝶多样性研究进 展. 华中昆虫研究, 12, 124-128.]

Xiang Y, Liu SQ, Zhao X, Hu Q, Tan AQ, Zhang YX, Liu ZX, Ma FZ (2017) Diversity and faunal analysis of butterflies within and outside the Huangsang National Nature Reserve of Hunan. International Journal of Ecology, 6(2), 27-41. (in Chinese with English abstract) [向颖, 刘素群, 赵欣, 胡强, 谭安琪, 张佑祥, 刘志霄, 马方舟 (2017) 湖南黄桑国家 级自然保护区及其周边蝶类多样性及区系分析. 世界生 态学, 6(2), 27-41.]

Xu HG, Cao MC, Wu Y, Cai L, Cao Y, Ding H, Cui P, Wu J, Wang Z, Le ZF, Lu XQ, Liu L, Li JQ (2017) Optimized monitoring sites for detection of biodiversity trends in China. Biodiversity and Conservation, 26, 1959-1971.

Zamora J, Verdú JR, Galante E (2007) Species richness in Mediterranean agroecosystems: Spatial and temporal analysis for biodiversity conservation. Biological Conservation, 134, 1-121.

Zhang WW, Li YS (2011) Chinese Insects Illustrated. Chongqing University Press, Chongqing. (in Chinese) [张巍 巍, 李元胜 (2011) 中国昆虫生态大图鉴. 重庆大学出版 社, 重庆.]

Zhang YX, Liu ZX, Yu GQ (2007) Faunistic structure and vertical distribution of butterflies in Hupingshan National Nature Reserve, Hunan. Sichuan Journal of Zoology, 26, 892-897. (in Chinese with English abstract) [张佑祥, 刘志 霄, 于桂清 (2007) 湖南壹瓶山国家级自然保护区蝶类 区系组成及垂直分布的初步研究. 四川动物, 26, 892-897.]

Zhang YL (1998) Coefficient of similarity: An important parameter in floristic geography. Geographical Research, 17, 429-434. (in Chinese with English abstract) [张镱锂 (1998) 植物区系地理研究中的重要参数——相似性系 数. 地理研究, 17, 429-434.]

(责任编委：白明 责任编辑：间文杰)

\section{附录 Supplementary Material}


陈梦悦, 吴雨恒, 廖承清, 马方舟, 王星 (2020) 八大公山国家级自然保护区不同生境蝶类群落特征与月动态. 生物多样性, 28(8): 950-957. http://www.biodiversity-science.net/CN/10.17520/biods.2019333

附录1 八大公山国家级自然保护区蝴蝶名录

Appendix 1 List of butterfly species recorded in the Badagongshan National Nature Reserve

\begin{tabular}{|c|c|c|c|c|c|c|c|c|}
\hline \multirow{3}{*}{$\begin{array}{l}\text { 科 } \\
\text { Family }\end{array}$} & \multirow{3}{*}{$\begin{array}{l}\text { 属 } \\
\text { Genus }\end{array}$} & \multirow{3}{*}{$\begin{array}{l}\text { 种 } \\
\text { Species }\end{array}$} & \multirow{2}{*}{\multicolumn{5}{|c|}{$\begin{array}{l}\text { 生境物种数量 } \\
\text { Species number in the habitat }\end{array}$}} & \multirow{3}{*}{$\begin{array}{l}\text { 合计 } \\
\text { Total }\end{array}$} \\
\hline & & & & & & & & \\
\hline & & & A & $\mathrm{B}$ & $\mathrm{C}$ & $\mathrm{D}$ & $\mathrm{E}$ & \\
\hline \multirow[t]{12}{*}{ 粉蝶科 Pieridae } & 斑粉蝶属 Delias & 酒青斑粉蝶 Delias sanaca (Moore, 1857) & 0 & 0 & 1 & 66 & 64 & 131 \\
\hline & 豆粉蝶属 Colias & 橙黄豆粉蝶 Colias fieldii (Ménétriès, 1855) & 0 & 0 & 0 & 1 & 2 & 3 \\
\hline & 方粉蝶属 Dercas & 黑角方粉蝶 Dercas lycorias (Doubleday, 1842) & 37 & 71 & 22 & 5 & 2 & 137 \\
\hline & 飞龙粉蝶 Talbotia & 飞龙粉蝶 Talbotia naganum Moore, 1884 & 2 & 0 & 6 & 155 & 156 & 319 \\
\hline & 粉蝶属 Pieris & 暗脉粉蝶 Pieris napi (Linnaeus, 1758) & 0 & 0 & 0 & 0 & 1 & 1 \\
\hline & & 菜粉蝶 Pieris rapae (Linnaeus, 1758) & 3 & 1 & 4 & 0 & 2 & 10 \\
\hline & & 东方菜粉蝶 Pieris canidia (Sparrman, 1768) & 26 & 87 & 33 & 15 & 9 & 170 \\
\hline & & 黑纹粉蝶 Pieris melete Ménétriés, 1857 & 11 & 14 & 39 & 251 & 284 & 599 \\
\hline & 钩粉蝶属 Gonepteryx & 圆翅钩粉蝶 Gonepteryx amintha (Blanchard, 1871) & 4 & 29 & 2 & 2 & 6 & 43 \\
\hline & 黄粉蝶属 Eurema & 宽边黄粉蝶 Eurema hecabe (Linnaeus, 1758) & 302 & 62 & 23 & 20 & 13 & 420 \\
\hline & 绢粉蝶属 Aporia & 大翅绢粉蝶 Aporia largeteaui (Oberthür, 1881) & 18 & 22 & 6 & 6 & 1 & 53 \\
\hline & & 小榄绢粉蝶 Aporia hippia (Bremer, 1861) & 1 & 2 & 1 & 1 & 1 & 6 \\
\hline \multirow[t]{19}{*}{ 凤蝶科 Papilionidae } & 凤蝶属 Papilio & 巴黎翠凤蝶 Papilio paris Linnaeus, 1758 & 72 & 103 & 8 & 7 & 1 & 191 \\
\hline & & 碧翠风蝶 Papilio bianor Cramer, [1778] & 90 & 165 & 38 & 38 & 11 & 342 \\
\hline & & 柑橘凤蝶 Papilio xuthus Linnaeus, 1767 & 1 & 0 & 0 & 0 & 0 & 1 \\
\hline & & 红基美风蝶 Papilio alcmenor Felder, 1864 & 9 & 4 & 1 & 0 & 1 & 15 \\
\hline & & 金凤蝶 Papilio machaon Linnaeus, 1758 & 0 & 0 & 0 & 1 & 1 & 2 \\
\hline & & 宽带美凤蝶 Papilio nephelus Boisduval, 1836 & 155 & 72 & 27 & 4 & 0 & 258 \\
\hline & & 宽尾凤蝶 Papilio elwesi Leech, 1889 & 2 & 1 & 1 & 0 & 1 & 5 \\
\hline & & 蓝美风蝶 Papilio protenor Cramer, [1775] & 56 & 45 & 12 & 10 & 4 & 127 \\
\hline & & 美凤蝶 Papilio memnon Linnaeus, 1758 & 6 & 6 & 3 & 1 & 3 & 19 \\
\hline & & 穹翠风蝶 Papilio dialis (Leech, 1893) & 5 & 20 & 4 & 2 & 1 & 32 \\
\hline & & 玉斑美凤蝶 Papilio helenus Linnaeus, 1758 & 119 & 54 & 6 & 2 & 2 & 183 \\
\hline & & 玉带美凤蝶 Papilio polytes Linnaeus, 1758 & 0 & 1 & 0 & 0 & 0 & 1 \\
\hline & & 窄斑翠凤蝶 Papilio arcturus Westwood, 1842 & 0 & 1 & 1 & 0 & 0 & 2 \\
\hline & 钩凤蝶属 Meandrusa & 褐钩凤蝶 Meandrusa sciron (Leech, 1890) & 0 & 0 & 0 & 4 & 1 & 5 \\
\hline & 青凤蝶属 Graphium & 宽带青凤蝶 Graphium cloantha Westwood, 1841 & 1 & 5 & 0 & 0 & 0 & 6 \\
\hline & & 黎氏青凤蝶 Graphium leechi Rothschild, 1895 & 7 & 40 & 1 & 26 & 15 & 89 \\
\hline & & 青凤蝶 Graphium sarpedon (Linnaeus, 1758) & 6 & 11 & 0 & 4 & 1 & 22 \\
\hline & 裳凤蝶属 Troides & 金裳凤蝶 Troides aeacus (Felder \& Felder, 1860) & 0 & 1 & 4 & 0 & 0 & 5 \\
\hline & 榭凤蝶属 Byasa & 灰线膺风蝶 Byasa mencia (Felder \& Felder, 1862) & 2 & 14 & 0 & 0 & 0 & 16 \\
\hline \multirow[t]{6}{*}{ 灰蝶科 Lycaenidae } & 波蚬蝶属 Zemeros & 波蚬蝶 Zemeros flegyas Cramer, 1780 & 105 & 33 & 1 & 1 & 0 & 140 \\
\hline & 彩灰蝶属 Heliophorus & 摩来彩灰蝶 Heliophorus moorei (Hewitson, 1865) & 0 & 0 & 0 & 0 & 2 & 2 \\
\hline & & 浓紫彩灰蝶 Heliophorus ila De Nicéville, 1896 & 0 & 1 & 0 & 1 & 1 & 3 \\
\hline & & 莎菲彩灰蝶 Heliophorus saphir Blanchard, 1871 & 6 & 10 & 2 & 5 & 3 & 26 \\
\hline & 靛灰蝶 Caerulea & 扣靛灰蝶 Caerulea coelestis (Alphéraky, 1897) & 0 & 0 & 0 & 19 & 27 & 46 \\
\hline & 褐蚬蝶属 Abisara & 白带褐蚬蝶 Abisara fylloides Moore, 1901 & 7 & 1 & 0 & 10 & 19 & 37 \\
\hline
\end{tabular}


陈梦悦, 吴雨恒, 廖承清, 马方舟, 王星 (2020) 八大公山国家级自然保护区不同生境蝶类群落特征与月动态. 生物多样性, 28(8): 950-957. http://www.biodiversity-science.net/CN/10.17520/biods.2019333

\begin{tabular}{|c|c|c|c|c|c|c|c|c|}
\hline \multirow{3}{*}{$\begin{array}{l}\text { 科 } \\
\text { Family }\end{array}$} & \multirow{3}{*}{$\begin{array}{l}\text { 属 } \\
\text { Genus }\end{array}$} & \multirow{3}{*}{$\begin{array}{l}\text { 种 } \\
\text { Species }\end{array}$} & \multicolumn{5}{|c|}{$\begin{array}{l}\text { 生境物种数量 } \\
\text { Species number in the habitat }\end{array}$} & \multirow{3}{*}{$\begin{array}{l}\text { 合计 } \\
\text { Total }\end{array}$} \\
\hline & & & & & & & & \\
\hline & & & A & B & C & D & E & \\
\hline & & 黄带褐蚬蝶 Abisara fylla (Westwood, [1851]) & 22 & 1 & 3 & 3 & 13 & 42 \\
\hline & 金灰蝶属 Chrysozephyrus & 闪光金灰蝶 Chrysozephyrus scintillans Leech, 1893 & 1 & 0 & 0 & 0 & 0 & 1 \\
\hline & 锯灰蝶属 Orthomiella & 中华锯灰蝶 Orthomiella sinensis (Elwes, 1887) & 0 & 0 & 0 & 2 & 7 & 9 \\
\hline & 蓝灰蝶属 Everes & 蓝灰蝶 Everes argiades (Pallas, 1771) & 1 & 0 & 0 & 0 & 1 & 2 \\
\hline & 亮灰蝶属 Lampides & 亮灰蝶 Lampides boeticus (Linnaeus, 1767) & 1 & 0 & 0 & 0 & 2 & 3 \\
\hline & 钮灰蝶属 Acytolepis & 钮灰蝶 Acytolepis puspa (Horsfield, 1828) & 10 & 9 & 0 & 0 & 0 & 19 \\
\hline & 生灰蝶属 Sinthusa & 生灰蝶 Sinthusa chandrana (Moore, 1882) & 1 & 1 & 0 & 0 & 0 & 2 \\
\hline & 丸灰蝶属 Pithecops & 黑丸灰蝶 Pithecops corvus Fruhstorfer, 1919 & 9 & 1 & 0 & 0 & 0 & 10 \\
\hline & 尾蚬蝶属 Dodona & 银纹尾蚬蝶 Dodona eugenes Bates, 1867 & 3 & 1 & 0 & 1 & 0 & 5 \\
\hline & 妩灰蝶属 Udara & 白斑妩灰蝶 Udara albocaerulea (Moore, 1879) & 2 & 0 & 1 & 0 & 1 & 4 \\
\hline & & 妩灰蝶 Udara dilecta (Moore, 1879) & 4 & 13 & 9 & 20 & 14 & 60 \\
\hline & 线灰蝶属 Spindasis & 豆粒银线灰蝶 Spindasis syama Horsfidld, 1829 & 3 & 1 & 1 & 1 & 0 & 6 \\
\hline & 玄灰蝶属 Tongeia & 波太玄灰蝶 Tongeia potanini (Alpheraky, 1892) & 4 & 2 & 0 & 0 & 0 & 6 \\
\hline & & 点玄灰蝶 Tongeia filicaudis (Pryer, 1877) & 20 & 43 & 19 & 14 & 10 & 106 \\
\hline & Y灰蝶属 Amblopala & Ү灰蝶 Amblopala avidiena (Hewitson, 1877) & 0 & 0 & 1 & 0 & 0 & 1 \\
\hline & 蚜灰蝶属 Taraka & 蚜灰蝶 Taraka hamada Druce, 1875 & 6 & 2 & 3 & 0 & 1 & 12 \\
\hline & 雅灰蝶属 Jamides & 雅灰蝶 Amblopala avidiena (Hewitson, 1877) & 6 & 2 & 1 & 0 & 0 & 9 \\
\hline & 燕灰蝶属 Rapala & 高沙子燕灰蝶 Rapala takasagonis Matsumura, 1929 & 0 & 1 & 0 & 0 & 0 & 1 \\
\hline & & 霓纱燕灰蝶 Rapala nissa (Kollar, 1844) & 2 & 2 & 0 & 0 & 1 & 5 \\
\hline & & 燕灰蝶 Rapala varuna Horsfield, 1829 & 1 & 2 & 1 & 0 & 1 & 5 \\
\hline & 银灰蝶属 Curetis & 尖翅银灰蝶 Curetis acuta Moore, 1877 & 38 & 23 & 6 & 2 & 0 & 69 \\
\hline & 酢浆灰蝶属 Pseudozizeeria & 酢浆灰蝶 Pseudozizeeria maha (Kollar, [1848]) & 21 & 41 & 25 & 17 & 13 & 117 \\
\hline 蛱蝶科 Nymphalidae & 鳌蛱蝶属 Charaxes & 白带鳌蛱蝶 Charaxes bernardus (Fabricius), 1793 & 0 & 0 & 2 & 0 & 0 & 2 \\
\hline & 奥蛱蝶属 Auzakia & 奥蛱蝶 Auzakia danava (Moore, 1858) & 0 & 1 & 0 & 2 & 0 & 3 \\
\hline & 白蛱蝶属 Helcyra & 傲白蛱蝶 Helcyra superba Leech, 1890 & 9 & 6 & 7 & 0 & 0 & 22 \\
\hline & & 银白蛱蝶 Helcyra subalba (Poujade, 1885) & 0 & 2 & 3 & 0 & 0 & 5 \\
\hline & 斑蝶属 Danaus & 虎斑蝶 Danaus genutia Cramer, 1779 & 1 & 1 & 0 & 2 & 0 & 4 \\
\hline & 斑眼蝶属 Penthema & 白斑眼蝶 Penthema adelma Felder, 1862 & 3 & 3 & 1 & 1 & 0 & 8 \\
\hline & 豹蛱蝶属 Argynnis & 绿豹蛱蝶 Argynnis paphia Linnaeus, 1758 & 0 & 0 & 1 & 3 & 3 & 7 \\
\hline & 串珠环蝶属 Faunis & 灰翅串珠环蝶 Faunis aerope Leech, 1890 & 0 & 0 & 10 & 0 & 0 & 10 \\
\hline & 窗蛱蝶属 Dilipa & 明窗蛱蝶 Dilipa fenestra (Leech, 1891) & 0 & 1 & 0 & 0 & 0 & 1 \\
\hline & 翠蛱蝶属 Euthalia & 黄铜翠蛱蝶 Euthalia nara Moore, 1859 & 0 & 1 & 1 & 1 & 0 & 3 \\
\hline & & 嘉翠蛱蝶 Euthalia kardama Moore, 1859 & 26 & 8 & 9 & 1 & 4 & 48 \\
\hline & & 孔子翠蛱蝶 Euthalia confucius Westwood, [1850] & 2 & 1 & 0 & 0 & 0 & 3 \\
\hline & & 西藏翠蛱蝶 Euthalia thibetana Poujade, 1886 & 27 & 0 & 0 & 0 & 1 & 28 \\
\hline & 带蛱蝶属 Athyma & 倒钩带蛱蝶 Athyma recurva Leech, 1893 & 0 & 1 & 0 & 0 & 0 & 1 \\
\hline & & 孤斑带蛱蝶 Athyma zeroca Moore, 1872 & 4 & 14 & 0 & 0 & 4 & 22 \\
\hline & & 离斑带蛱蝶 Athyma ranga moore, 1857 & 1 & 0 & 0 & 0 & 0 & 1 \\
\hline & & 六点带蛱蝶 Athyma punctata Leech, 1890 & 0 & 0 & 0 & 1 & 0 & 1 \\
\hline
\end{tabular}


陈梦悦, 吴雨恒, 廖承清, 马方舟, 王星 (2020) 八大公山国家级自然保护区不同生境蝶类群落特征与月动态. 生物多样性, 28(8): 950-957. http://www.biodiversity-science.net/CN/10.17520/biods.2019333

\begin{tabular}{|c|c|c|c|c|c|c|c|c|}
\hline \multirow[t]{2}{*}{$\begin{array}{l}\text { 科 } \\
\text { Family }\end{array}$} & \multirow[t]{2}{*}{$\begin{array}{l}\text { 属 } \\
\text { Genus }\end{array}$} & \multirow[t]{2}{*}{$\begin{array}{l}\text { 种 } \\
\text { Species }\end{array}$} & \multicolumn{5}{|c|}{$\begin{array}{l}\text { 生境物种数量 } \\
\text { Species number in the habitat }\end{array}$} & \multirow[t]{2}{*}{$\begin{array}{l}\text { 合计 } \\
\text { Total }\end{array}$} \\
\hline & & & A & $\mathrm{B}$ & $\mathrm{C}$ & $\mathrm{D}$ & $\mathrm{E}$ & \\
\hline & & 虬眉带蛱蝶Ａthyma opalina (Kollar, 1844) & 1 & 3 & 1 & 0 & 0 & 5 \\
\hline & & 新月带蛱蝶 Athyma selenophora (Kollar, [1844]) & 1 & 2 & 0 & 3 & 4 & 10 \\
\hline & & 玉杵带蛱蝶 Athyma jina (Moore, 1857) & 46 & 15 & 8 & 5 & 3 & 77 \\
\hline & & 珠履带蛱蝶 Athyma asure Moore, 1858 & 7 & 1 & 0 & 0 & 0 & 8 \\
\hline & 黛眼蝶属 Lethe & 白带黛眼蝶 Lethe confusa Aurivillius, 1897 & 0 & 0 & 0 & 0 & 1 & 1 \\
\hline & & 白条黛眼蝶 Lethe albolineata Poujade, 1884 & 0 & 0 & 0 & 1 & 0 & 1 \\
\hline & & 黛眼蝶 Chonala episcopalis (Oberthür, 1885) & 0 & 0 & 0 & 0 & 1 & 1 \\
\hline & & 连纹黛眼蝶 Lethe syrcis Doubleday, [1849] & 0 & 0 & 0 & 1 & 0 & 1 \\
\hline & & 孪斑黛眼蝶 Lethe gemina Leech, 1891 & 2 & 0 & 1 & 0 & 2 & 5 \\
\hline & & 深山黛眼蝶 Lethe insana Kollar, 1844 & 0 & 2 & 0 & 3 & 2 & 7 \\
\hline & & 玉带黛眼蝶 Lethe verma Kollar, 1844 & 3 & 5 & 12 & 14 & 40 & 74 \\
\hline & & 直带黛眼蝶 Lethe lanaris Butler, 1877 & 0 & 0 & 2 & 3 & 2 & 7 \\
\hline & & 棕褐黛眼蝶 Lethe christophi Leech, 1891 & 0 & 2 & 2 & 3 & 2 & 9 \\
\hline & 颠眼蝶属 Acropolis & 颠眼蝶 Acropolis thalia Leech, 1891 & 5 & 1 & 5 & 0 & 0 & 11 \\
\hline & 电蛱蝶属 Dichorragia & 电蛱蝶 Dichorragia nesimachus Boisduval, 1836 & 1 & 0 & 1 & 0 & 0 & 2 \\
\hline & 妸蛱蝶属 Abrota & 婀蛱蝶 Abrota ganga Moore, 1857 & 1 & 0 & 0 & 0 & 0 & 1 \\
\hline & 斐豹蛱蝶属 Argyreus & 斐豹蛱蝶 Argyreus hyperbius Linnaeus, 1763 & 6 & 10 & 1 & 17 & 17 & 51 \\
\hline & 钩蛱蝶属 Polygonia & 黄钩蛱蝶 Polygonia caureum (Linnaeus, 1758) & 1 & 0 & 0 & 0 & 0 & 1 \\
\hline & 红蛱蝶属 Vanessa & 大红蛱蝶 Vanessa indica Herbst, 1794 & 4 & 4 & 0 & 8 & 3 & 19 \\
\hline & & 小红蛱蝶 Vanessa cardui Linnaeus, 1758 & 1 & 0 & 0 & 6 & 0 & 7 \\
\hline & 环蛱蝶属 Neptis & 阿环蛱蝶 Neptis ananta Moore, 1857 & 6 & 0 & 1 & 0 & 0 & 7 \\
\hline & & 断环蛱蝶 Neptis sankara Kollar, 1844 & 3 & 3 & 1 & 0 & 1 & 8 \\
\hline & & 黄环蛱蝶 Neptis themis Leech, 1893 & 3 & 0 & 1 & 2 & 1 & 7 \\
\hline & & 黄重环蛱蝶 Neptis cydippe Leech, 1890 & 0 & 0 & 1 & 0 & 0 & 1 \\
\hline & & 卡环蛱蝶 Neptis cartica Moore, 1872 & 1 & 0 & 0 & 0 & 0 & 1 \\
\hline & & 柯环蛱蝶 Neptis clinia Moore, 1872 & 0 & 0 & 1 & 0 & 0 & 1 \\
\hline & & 链环蛱蝶 Neptis pryeri Butler, 1871 & 0 & 0 & 0 & 8 & 5 & 13 \\
\hline & & 玛环蛱蝶 Neptis manasa Moore, 1857 & 4 & 0 & 0 & 0 & 1 & 5 \\
\hline & & 矛环蛱蝶 Neptis armandia Oberthür, 1876 & 2 & 0 & 6 & 0 & 1 & 9 \\
\hline & & 弥环蛱蝶 Neptis miah Moore, 1857 & 31 & 20 & 3 & 4 & 1 & 59 \\
\hline & & 司环蛱蝶 Neptis speyeri Staudinger, 1887 & 0 & 2 & 0 & 0 & 0 & 2 \\
\hline & & 娑环蛱蝶 Neptis soma Moore, 1858 & 70 & 49 & 26 & 14 & 9 & 168 \\
\hline & & 提环蛱蝶 Neptis thisbe Ménétriés, 1859 & 0 & 2 & 0 & 0 & 0 & 2 \\
\hline & & 小环蛱蝶 Neptis sappho Pallas, 1771 & 26 & 13 & 8 & 4 & 4 & 55 \\
\hline & & 折环蛱蝶 Neptis beroe Leech, 1890 & 9 & 7 & 0 & 5 & 1 & 22 \\
\hline & & 中环蛱蝶 Neptis hylas Linnaeus, 1758 & 0 & 0 & 0 & 1 & 0 & 1 \\
\hline & 喙蝶属 Libythea & 朴喙蝶 Libythea lepita Moore, 1857 & 10 & 9 & 17 & 17 & 20 & 73 \\
\hline & 箭环蝶属 Stichophthalma & 箭环蝶 Stichophthalma howqua Westwood, 1851 & 4 & 8 & 1 & 1 & 0 & 14 \\
\hline & & 双星箭环蝶 Stichophthalma neumogeni Leech, 1892 & 0 & 2 & 2 & 0 & 0 & 4 \\
\hline
\end{tabular}


陈梦悦, 吴雨恒, 廖承清, 马方舟, 王星 (2020) 八大公山国家级自然保护区不同生境蝶类群落特征与月动态. 生物多样性, 28(8): 950-957. http://www.biodiversity-science.net/CN/10.17520/biods.2019333

\begin{tabular}{|c|c|c|c|c|c|c|c|c|}
\hline \multirow[t]{2}{*}{$\begin{array}{l}\text { 科 } \\
\text { Family }\end{array}$} & \multirow[t]{2}{*}{$\begin{array}{l}\text { 属 } \\
\text { Genus }\end{array}$} & \multirow[t]{2}{*}{$\begin{array}{l}\text { 种 } \\
\text { Species }\end{array}$} & \multicolumn{5}{|c|}{$\begin{array}{l}\text { 生境物种数量 } \\
\text { Species number in the habitat }\end{array}$} & \multirow[t]{2}{*}{$\begin{array}{l}\text { 合计 } \\
\text { Total }\end{array}$} \\
\hline & & & A & $\mathrm{B}$ & $\mathrm{C}$ & $\mathrm{D}$ & $\mathrm{E}$ & \\
\hline & \multirow[t]{2}{*}{ 绢斑蝶属 Parantica } & 大绢斑蝶 Parantica sita Kollar, 1844 & 0 & 0 & 0 & 1 & 1 & 2 \\
\hline & & 大卫绢蛱蝶 Calinaga davidis Oberthür, 1879 & 3 & 0 & 0 & 1 & 3 & 7 \\
\hline & \multirow[t]{7}{*}{ 翄眼蝶属 Ypthima } & 东亚榎眼蝶 Ypthima motschulskyi Bremer \& Grey, 1853 & 0 & 0 & 1 & 3 & 0 & 4 \\
\hline & & 翟眼蝶 Ypthima balda Fabricius, 1775 & 7 & 22 & 13 & 11 & 13 & 66 \\
\hline & & 魔女賏眼蝶 Ypthima medusa Leech, 1892-1894 & 1 & 1 & 12 & 10 & 5 & 29 \\
\hline & & 完璧賏眼蝶 Ypthima perfecta Leech, 1892 & 0 & 0 & 0 & 0 & 1 & 1 \\
\hline & & 幽翟眼蝶 Ypthima conjumcta Leech, 1891 & 0 & 1 & 0 & 0 & 0 & 1 \\
\hline & & 中华翄眼蝶 Ypthima chinensis Leech, 1892 & 0 & 0 & 0 & 0 & 3 & 3 \\
\hline & & 卓眐眼蝶 Ypthima zodia Butler, 1871 & 0 & 0 & 0 & 1 & 7 & 8 \\
\hline & 铠蛱蝶属 Chitoria & 铂铠蛱蝶 Chitoria pallas (Leech, 1890) & 0 & 0 & 0 & 1 & 0 & 1 \\
\hline & 枯叶蛱蝶属 Kallima & 枯叶蛱蝶 Kallima inachus Boisduval, 1836 & 12 & 4 & 2 & 0 & 0 & 18 \\
\hline & 老豹蛱蝶属 Argyronome & 老豹蛱蝶 Argyronome laodice Pallas, 1771 & 1 & 1 & 0 & 1 & 0 & 3 \\
\hline & 丽眼蝶属 Mandarinia & 蓝斑丽眼蝶 Mandarinia regalis Leech, 1889 & 3 & 1 & 0 & 2 & 5 & 11 \\
\hline & 琉璃蛱蝶属 Kaniska & 琉璃蛱蝶 Kaniska canace (Linnaeus, 1763) & 1 & 4 & 1 & 8 & 5 & 19 \\
\hline & \multirow[t]{2}{*}{ 脉蛱蝶属 Hestina } & 黑脉蛈蝶 Hestina assimilis Linnaeus, 1758 & 2 & 3 & 1 & 0 & 1 & 7 \\
\hline & & 拟斑脉蛱蝶 Hestina persimilis Westwood, [1850] & 9 & 13 & 1 & 2 & 0 & 25 \\
\hline & \multirow[t]{2}{*}{ 猫蛱蝶属 Timelaea } & 白裳猫蛱蝶 Timelaea albescens (Oberthür, 1886) & 11 & 2 & 1 & 1 & 3 & 18 \\
\hline & & 猫蛱蝶 Timelaea maculata Bremer \& Grey, 1853 & 1 & 1 & 0 & 0 & 0 & 2 \\
\hline & \multirow[t]{2}{*}{ 眉眼蝶属 Mycalesis } & 稻眉眼蝶 Mycalesis gotama Moore, 1857 & 0 & 0 & 0 & 3 & 4 & 7 \\
\hline & & 拟稻眉眼蝶 Mycalesis francisca Cramer, 1782 & 0 & 2 & 0 & 0 & 1 & 3 \\
\hline & 迷蛱蝶属 Mimathyma & 白斑迷蛱蝶 Mimathyma schrenckii Ménétriès, 1859 & 2 & 3 & 1 & 0 & 0 & 6 \\
\hline & \multirow[t]{2}{*}{ 暮眼蝶属 Melanitis } & 睇暮眼蝶 Melanitis phedima Cramer, 1782 & 0 & 1 & 0 & 0 & 0 & 1 \\
\hline & & 暮眼蝶 Melanitis leda Linnaeus, 1758 & 1 & 1 & 1 & 1 & 1 & 5 \\
\hline & 俳蛱蝶属 Parasarpa & 白斑俳蛱蝶 Parasarpa albomaculata (Leech, 1891) & 0 & 0 & 0 & 1 & 2 & 3 \\
\hline & \multirow[t]{2}{*}{ 闪蛱蝶属 Apatura } & 柳紫闪蛱蝶 Apatura ilia (Denis \& Schiffermuller, 1775) & 0 & 0 & 0 & 0 & 1 & 1 \\
\hline & & 紫闪蛱蝶 Apatura iris Linnaeus, 1758 & 0 & 1 & 0 & 0 & 0 & 1 \\
\hline & \multirow[t]{2}{*}{ 盛蛱蝶属 Symbrenthia } & 花豹盛蛱蝶 Symbrenthia hypselis Godart, 1823 & 45 & 6 & 3 & 4 & 4 & 62 \\
\hline & & 散纹盛蛱蝶 Symbrenthia lilaea Hewitson, 1864 & 28 & 13 & 0 & 2 & 1 & 44 \\
\hline & 饰蛱蝶属 Stibochiona & 素饰蛱蝶 Stibochiona nicea Gray, 1846 & 25 & 15 & 11 & 4 & 1 & 56 \\
\hline & 帅蛱蝶属 Sephisa & 黄帅蛱蝶 Sephisa princeps Fixsen, 1887 & 1 & 2 & 0 & 7 & 1 & 11 \\
\hline & 丝蛱蝶属 Cyrestis & 网丝蛱蝶 Cyrestis thyodamas Boisdamas, 1836 & 1 & 0 & 0 & 0 & 0 & 1 \\
\hline & 网眼蝶属 Rhaphicera & 网眼蝶 Rhaphicera dumicola Oberthür, 1876 & 0 & 0 & 0 & 0 & 1 & 1 \\
\hline & 尾蛱蝶属 Polyura & 二尾蛱蝶 Polyura narcaea Hewitson, 1854 & 131 & 38 & 0 & 3 & 0 & 172 \\
\hline & \multirow[t]{3}{*}{ 线蛱蝶属 Limenitis } & 残锣线蛱蝶 Limenitis sulpitia (Cramer, [1779]) & 3 & 1 & 0 & 0 & 0 & 4 \\
\hline & & 断眉线蛱蝶 Limenitis doerriesi Staudinger, 1892 & 11 & 1 & 0 & 0 & 0 & 12 \\
\hline & & 横眉线蛱蝶 Limenitis moltrechti Kardakoff, 1928 & 0 & 0 & 0 & 0 & 2 & 2 \\
\hline & 秀蛱蝶属 Pseudergolis & 秀蛱蝶 Pseudergolis wedah Kollar, 1848 & 34 & 37 & 33 & 2 & 1 & 107 \\
\hline & 眼蛱蝶属 Junonia & 钩翅眼蛱蝶 Junonia iphita Cramer, 1782 & 6 & 0 & 0 & 0 & 0 & 6 \\
\hline & 荫眼蝶属 Neope & 黄斑荫眼蝶 Neope pulaha Moore, 1857 & 0 & 2 & 0 & 27 & 14 & 43 \\
\hline
\end{tabular}


陈梦悦, 吴雨恒, 廖承清, 马方舟, 王星 (2020) 八大公山国家级自然保护区不同生境蝶类群落特征与月动态. 生物多样性, 28(8): 950-957. http://www.biodiversity-science.net/CN/10.17520/biods.2019333

\begin{tabular}{|c|c|c|c|c|c|c|c|c|}
\hline \multirow{3}{*}{$\begin{array}{l}\text { 科 } \\
\text { Family }\end{array}$} & \multirow{3}{*}{$\begin{array}{l}\text { 属 } \\
\text { Genus }\end{array}$} & \multirow{3}{*}{$\begin{array}{l}\text { 种 } \\
\text { Species }\end{array}$} & \multicolumn{5}{|c|}{$\begin{array}{l}\text { 生境物种数量 } \\
\text { Species number in the habitat }\end{array}$} & \multirow{3}{*}{$\begin{array}{l}\text { 合计 } \\
\text { Total }\end{array}$} \\
\hline & & & & & & & & \\
\hline & & & A & B & $\mathrm{C}$ & $\mathrm{D}$ & $\mathrm{E}$ & \\
\hline \multirow{37}{*}{ 弄蝶科 Heperiidae } & & 蒙链荫眼蝶 Neope muirheadii (C \& R Felder, 1862) & 0 & 0 & 0 & 0 & 1 & 1 \\
\hline & 银豹蛱蝶属 Childrena & 银豹蛱蝶 Childrena childreni Gray, 1831 & 0 & 0 & 0 & 1 & 0 & 1 \\
\hline & 珍蝶属 Acraea & 亖麻珍蝶 Acraea issoria Hubner, 1816 & 0 & 0 & 0 & 0 & 1 & 1 \\
\hline & 蜘蛱蝶 Araschnia & 曲纹蜘蛱蝶 Araschnia doris Leech, 1892 & 9 & 5 & 3 & 9 & 2 & 28 \\
\hline & 紫蛱蝶属 Sasakia & 大紫蛱蝶 Sasakia charonda Hewitson, 1862 & 8 & 4 & 2 & 0 & 0 & 14 \\
\hline & 白弄蝶属 Abraximorpha & 白弄蝶 Abraximorpha davidii Mabille, 1876 & 6 & 3 & 1 & 4 & 1 & 15 \\
\hline & 豹弄蝶属 Thymelicus & 黑豹弄蝶 Thymelicus sylvaticus Bremer, 1861 & 2 & 0 & 2 & 2 & 1 & 7 \\
\hline & 稻弄蝶属 Parnara & 曲纹稻弄蝶 Parnara ganga Evans, 1937 & 0 & 0 & 0 & 2 & 5 & 7 \\
\hline & 谷弄蝶属 Pelopidas & 隐纹谷弄蝶 Pelopidas mathias Fabricius, 1798 & 1 & 0 & 0 & 2 & 0 & 3 \\
\hline & & 直纹稻弄蝶 Parnara guttata Bremer er Grey, 1852 & 7 & 1 & 0 & 0 & 0 & 8 \\
\hline & 黑弄蝶属 Daimio & 黑弄蝶 Daimio tethys Ménétriès, 1857 & 15 & 6 & 4 & 6 & 3 & 34 \\
\hline & 黄斑弄蝶属 Ampittia & 钩形黄斑弄蝶 Ampittia virgata Leech, 1890 & 1 & 1 & 0 & 0 & 0 & 2 \\
\hline & 黄室弄蝶属 Potanthus & 锯纹黄室弄蝶 Potanthus lydia Evans, 1934 & 12 & 1 & 1 & 0 & 2 & 16 \\
\hline & 姜弄蝶属 Udaspes & 姜弄蝶 Udaspes folus Cramer, 1775 & 0 & 0 & 0 & 1 & 0 & 1 \\
\hline & 蕉弄蝶属 Erionota & 白斑蕉弄蝶 Erionota grandis Leech, 1890 & 3 & 0 & 0 & 0 & 0 & 3 \\
\hline & & 黄斑蕉弄蝶 Erionota torus Evans, 1941 & 0 & 0 & 0 & 2 & 1 & 3 \\
\hline & 捷弄蝶属 Gerosis & 匪夷捷弄蝶 Gerosis phisara (Moore, 1884) & 6 & 1 & 1 & 0 & 1 & 9 \\
\hline & & 中华捷弄蝶 Gerosis sinica (C \& R. Felder, 1862) & 1 & 0 & 0 & 1 & 0 & 2 \\
\hline & 襟弄蝶属 Pseudocoladenia & 黄襟弄蝶 Pseudocoladenia dea (Leech, 1894) & 1 & 0 & 1 & 3 & 1 & 6 \\
\hline & 胫弄蝶属 Baoris & 刺胫弄蝶 Baoris farri (Moore, 1878) & 1 & 0 & 0 & 0 & 0 & 1 \\
\hline & 珂弄蝶属 Caltoris & 放踵珂弄蝶 Caltoris cahira Moore, 1877 & 0 & 0 & 0 & 14 & 6 & 20 \\
\hline & 孔弄蝶属 Polytremis & 刺纹孔弄蝶 Polytremis zina Evans, 1932 & 4 & 13 & 0 & 0 & 7 & 24 \\
\hline & 绿弄蝶属 Choaspes & 绿弄蝶 Choaspes benjaminii Méneville, 1843 & 1 & 0 & 2 & 0 & 0 & 3 \\
\hline & 暮弄蝶属 Burara & 白暮弄蝶 Burara gomata (Moore, [1866]) & 2 & 0 & 0 & 0 & 0 & 2 \\
\hline & & 大暮弄蝶 Burara miracula Evans, 1949 & 1 & 0 & 0 & 0 & 0 & 1 \\
\hline & 讴弄蝶属 Onryza & 讴弄蝶 Onryza maga Leech, 1890 & 0 & 0 & 0 & 1 & 0 & 1 \\
\hline & 裙弄蝶属 Tagiades & 黑边裙弄蝶 Tagiades menaka Moore, 1865 & 0 & 1 & 0 & 0 & 0 & 1 \\
\hline & 飒弄蝶属 Satarupa & 密纹沨弄蝶 Satarupa monbeigi Oberthür, 1921 & 1 & 2 & 0 & 8 & 7 & 18 \\
\hline & 疏翅弄蝶属 Ctenoptilum & 疏翅弄蝶 Ctenoptilum vasava Moore, 1865 & 1 & 0 & 0 & 0 & 0 & 1 \\
\hline & 陀弄蝶属 Thoressa & 花裙陀弄蝶 Thoressa submacula Leech, 1890 & 16 & 1 & 0 & 0 & 0 & 17 \\
\hline & 无趾弄蝶属 Hasora & 无趾弄蝶 Hasora anura De Nicéville, 1889 & 0 & 0 & 1 & 1 & 8 & 10 \\
\hline & 星弄蝶属 Celaenorrhinus & 斑星弄蝶 Celaenorrhinus maculosus Felder, 1867 & 28 & 41 & 45 & 16 & 44 & 174 \\
\hline & & 小星弄蝶 Celaenorrhinus ratna Fruhstorfer, 1909 & 0 & 0 & 0 & 2 & 0 & 2 \\
\hline & 袖弄蝶属 Notocrypta & 曲纹袖弄蝶 Notocrypta curvifascia Felder \& Felder, 1862 & 9 & 0 & 0 & 1 & 0 & 10 \\
\hline & 旖弄蝶属 Isoteinon & 旖弄蝶 Isoteinon lamprospilus Felder \& Felder, 1862 & 43 & 4 & 1 & 1 & 1 & 50 \\
\hline & 长标弄蝶属 Telicota & 长标弄蝶 Telicota colon Fabricius, 1775 & 4 & 3 & 0 & 0 & 0 & 7 \\
\hline & 舟弄蝶属 Barca & 双色舟弄蝶 Barca bicolor Oberthür, 1896 & 0 & 0 & 0 & 0 & 8 & 8 \\
\hline
\end{tabular}

